\title{
Which quality of life scale should be used to evaluate acne vulgaris patients? CADI or DLQI? A prospective study
}

\author{
Akne vulgaris hastalarının değerlendirilmesi için hangi yaşam kalite ölçeği kullanılmalıdır? CADI ya \\ da DYKİ? Bir prospektif çalışma
}

Aslı Tatlıparmak ${ }^{1}$, Berna Aksoy ${ }^{1}$, Ayșe Serap Karadağ ${ }^{2}$

\section{Abstract}

Aim: Acne vulgaris is one of the most common diseases that affects quality of life. While the Dermatology Life Quality Index (DLQI) is the most frequently used life quality index for dermatologic disorders, the Cardiff Acne Disability Index (CADI) is an acne-spesific quality of life scale. The aim of this study was to determine which scale should be more appropriate and practical to evaluate the quality of life in acne patients and to compare the differences between two scales.

Methods: Acne scores of 273 patients who were admitted to the dermatology outpatient clinic between December 2015 and November 2016 were determined by the Global Acne Grading System (GAGS) (range 0 to 44). The DLQI (range 0 to 30 ) and CADI scores (range 0 to 20) were calculated to evaluate the effect of patients' quality of life.

Results: The mean GAGS score of the patients was 20.3, and the mean of CADI score was 6.1, while the mean of DLQI was 6.0. There was a significant positive correlation between total GAGS score and CADI and DLQI $(r=0.639, p<0.001)$. When the relationship between the distribution of acne lesions and quality of life scales was evaluated; CADI score was significantly higher in the forehead localization group than in the non-forehead localization group $(\mathrm{p}=0.012)$, and the CADI and DLQI scores were higher in the upper back group than the group without back localization ( $\mathrm{p}=0.001$ and $\mathrm{p}=0.017$ respectively).

Conclusion: In our study, it was observed that the DLQI and CADI scales were not superior to each other in evaluating the quality of life in patients with acne. Besides, we think that the effect of quality of life on facial acne cases can be determined more clearly with CADI scale.

Key Words: Acne, Cardiff Acne Disability Index, Dermatology Life Quality Index, quality of life.

\section{Öz}

Amaç: Akne vulgaris, sık görülen, kişinin yaşam kalitesini ve sosyal hayatını olumsuz yönde etkileyen dermatolojik bir hastalıktır. Klinik çalışmalarda, akne vulgarisin hastaların yaşam kalitesini olumsuz yönde etkileyen en sık hastalıklardan olduğu görülmektedir. Dermatolojik Yaşam Kalite İndeksi (DYKI); dermatolojik hastalıklar için yaygın olarak kullanılan bir indeks iken, Cardiff Akne Kısıtlılık İndeksi (CADI) akneye özgü değerlendirme skalası olarak kullanılmaktadır. Bu çalışmanın amacı, akne hastalarında hangi ölçeğin daha uygun ve pratik olduğunu tespit etmek ve iki skala arasındaki farkları değerlendirmektir

Yöntemler: Çalıșmamızda Aralık 2015- Kasım 2016 tarihleri arasında Dermatoloji polikliniğine bașvuran ve akne tanısı alan toplam 273 hastanın akne skorları Global Akne Skorlama Sistemi (GAGS) (aralık 0 ile 44 arası) ile belirlenip ardından DYKİ (aralık 0 ile 30 arası) ve CADI skorları (aralık 0 ile 20 arası) ile yaşam kalitesi belirlendi.

Sonuçlar: Hastaların GAGS skoru ortalaması 20,3, CADI skoru ortalaması 6,1 iken DYKİ ortalaması 6,0 idi. DYKİ ile CADI skorları arasında pozitif korelasyon mevcuttu $(\mathrm{r}=0,639, \mathrm{p}<0,001)$. Akne lezyonlarının dağıılımı ile yaşam kalite ölçekleri arasındaki ilişki değerlendirildiğinde; alın lokalizasyonu olan grupta CADI skoru, alın lokalizasyonu olmayan gruptan anlamlı olarak daha yüksekti $(\mathrm{p}=0,012)$. Sirt üst lokalizasyonu olan grupta CADI ve DYKİ skoru sırt lokalizasyonu olmayan gruptan anlamlı olarak daha yüksekti (sirasıyla $p=0,001$ ve $p=$ $0,017)$.

Tartışma: Calıșmamızda DYKİ ve CADI yaşam ölçeklerinin, akne tanılı olgularda yașam kalitesin değerlendirmede birbirine üstünlükleri olmadığı ancak yüz yerleşimli akne vakalarında yaşam kalitesinin etkilenme düzeyinin CADI skoru ile daha net belirlenebileceği gözlemlendi.

Anahtar Kelimeler: Akne vulgaris, Cardiff Akne Kısıtlılık İndeksi, Dermatolojik Yaşam Kalite İndeksi, yaşam kalitesi.
${ }^{1}$ Bahcesehir University, Faculty of Medicine, Department of Dermatology, Istanbul, Turkey.

2 Istanbul Medeniyet University, Faculty of Medicine, Department of Dermatology, Istanbul, Turkey.

Ethics Committee Approval: The study wass approved by the local ethical authority (2016/0240). Etik Kurul Onayı: Çalışma lokal etik komite tarafindan onaylanmıștır (2016/0240).

Conflict of Interest: No conflict of interest was declared by the authors.

Çıkar Çatışması: Yazarlar çıkar çatışması bildirmemişlerdir.

Financial Disclosure: The authors declared that this study has received no financial support. Finansal Destek: Yazarlar bu çalıșma için finansal destek almadıklarını beyan etmişlerdir.

Gelis Tarihi / Received: 15.06.2019

Kabul Tarihi / Accepted: 18.07.2019

Yayın Tarihi / Published: 01.08.2019

Sorumlu yazar / Corresponding author:

Asli Tatliparmak

Adres/Address: Department of Dermatology, Bahcesehir University, Faculty of Medicine, Istanbul, Turkey.

e-posta: aslitatliparmak@gmail.com

Tel/Phone: 0905326118537

Copyright $($ ACEM 


\section{Introduction}

Acne vulgaris is a skin disease that mainly affects adolescents. Although it is a benign condition, lesions have a significant negative impact on the patients' life [1]. Studies have shown that acne can be associated with a spectrum of psychosocial abnormalities including depression, suicidality, anxiety, psychosomatic symptoms and social inhibition [2].

The World Health Organization (WHO) defines quality of life as the individual's perception of their position in life in the context of the culture and value systems in which they live, and in relation to their goals, expectations, standards and concerns [3]. The measurement of life quality is important in the management, and determines the impact of the disease and treatment outcomes on the patients [1].

The Dermatology Life Quality Index (DLQI) is widely used quality of life measurement in dermatology [4]. Cardiff Acne Disability Index (CADI) is an acne-specific quality of life scale. Selection of which scale for acne vulgaris patients still remains controversial.

The objective of this study was to determine which quality of life scale is more practical and appropriate for acne patients.

\section{Material and methods}

Patients with acne vulgaris who attended the Dermatology Outpatient Clinic between December 2015 and November 2016 were enrolled in the study. Patients who are pregnant or under the age of 18 were excluded from the study. Prior to initiation of the study, written informed consent was obtained from all participants. The study was conducted in accordance with the Declaration of Helsinki and approved by the local Clinical Research Ethics Committee (Medeniyet University, 2016/0240).

Age, gender, occupation, concominant diseases of the patients and their duration, localization and symptoms of acne vulgaris were recorded. Clinical assessment of acne was evaluated by the Global Acne Grading System (GAGS) [7]. In this scoring system, a coefficient (the forehead, the right cheek and the left cheek as 2, the nose and the chin as 1, the chest and the upper back as 3) for each area is taken into consideration by dividing the face, the chest and upper back into six parts, considering the width of the region and the density and distribution of the pilosebaceous units in that area. Acne lesions were also graded between $0-4$, depending on the severity (no lesions as $0, \geq 1$ comedones as $1, \geq 1$ papules as $2, \geq 1$ pustules as $3, \geq 1$ nodules as 4). After evaluating each area separately, multiplying the score obtained by the most severe lesion type in that area and multiplying the coefficient of that region, and determining a score for each area, the sum of the scores of the six regions and the GAGS scores were calculated. Total score ranges from 0 to 44, acne severity is determined according to GAGS score ( 0 for none, 1-18 points for mild, 19-30 for moderate, 3138 for severe, 39 for very severe) [7].

In order to assess the quality of life, the DLQI and the CADI scores were used both in each patient. The DLQI includes 10 questions with 4 possible answers that are designed to be based on the patient's symptoms, feelings, daily activity, leisure time, school/work life, personal relationships and treatment. In general, the severity of the disease affecting social and physical activations in the last week is determined. The score of DLQI varies between 0-30 [6]. CADI scale which consists of five questions, the questions are aimed to evaluate the psychological, emotional and social effects of acne in the last one month. Questions are given a score between1-4 and the score varies between $0-20$. The higher the score, the more affected the quality of life [7].

\section{Statistical analysis}

Mean with standard deviation, median with minimum and maximum, frequency and ratio were used in descriptive statistics of data. The distribution of the variables was measured by the Kolmogorov Smirnov test. The Mann-Whitney U test was used for the analysis of quantitative independent data and Spearman correlation analysis was used for correlation analysis. SPSS 22.0 program was used.

\section{Results}

A total of 273 patients, 213 females (78\%) and 60 males (22\%) were included in the study. The mean duration of acne was $67.9 \pm 61.6$ months. The most common localizations of the acne lesions were the cheek $(97.4 \%)$, the forehead $(93.4 \%)$, the perioral region $(92.7 \%)$ and the upper back $(71.1 \%)$ respectively (Table 1).

Table 1. Demographic and clinical characteristic of the patients.

\begin{tabular}{|c|c|c|}
\hline \multicolumn{2}{|l|}{ Variable } & Value \\
\hline \multicolumn{2}{|c|}{ Age (year) ${ }^{¥}$} & $23.4 \pm 6.4$ \\
\hline \multirow[t]{2}{*}{ Gender $^{\beta}$} & Female & $213(78)$ \\
\hline & Male & $60(22)$ \\
\hline \multicolumn{2}{|c|}{ Duration (month) ${ }^{\ddagger}$} & $67.9 \pm 61.6$ \\
\hline \multicolumn{2}{|c|}{ Concominant diseases ${ }^{¥}$} & $12(4.4)$ \\
\hline \multicolumn{3}{|c|}{ Lokalization } \\
\hline \multicolumn{2}{|c|}{ Forehead $^{\beta}$} & $255(93.4)$ \\
\hline \multicolumn{2}{|l|}{ Nose $^{\beta}$} & $142(52)$ \\
\hline \multicolumn{2}{|l|}{ Cheek $^{\beta}$} & $266(97.4)$ \\
\hline \multicolumn{2}{|c|}{ Perioral $^{\beta}$} & $253(92.7)$ \\
\hline \multicolumn{2}{|c|}{ Submental $^{\beta}$} & $61(22.3)$ \\
\hline \multicolumn{2}{|c|}{ Submandibular $^{\beta}$} & $147(53.8)$ \\
\hline \multicolumn{2}{|l|}{ Chest $^{\beta}$} & $157(57.5)$ \\
\hline \multicolumn{2}{|c|}{ Upper back $^{\beta}$} & $194(71.1)$ \\
\hline \multicolumn{2}{|c|}{ Lower back $^{\beta}$} & 57 (20.9) \\
\hline \multicolumn{3}{|c|}{ GAGS score } \\
\hline \multicolumn{2}{|c|}{ Forehead $^{¥}$} & $3.7 \pm 1.7$ \\
\hline \multicolumn{2}{|c|}{ Right cheek ${ }^{¥}$} & $4.2 \pm 1.8$ \\
\hline \multicolumn{2}{|c|}{ Left cheek ${ }^{¥}$} & $4.4 \pm 1.9$ \\
\hline \multicolumn{2}{|l|}{ Nose } & $0.9 \pm 1.1$ \\
\hline \multicolumn{2}{|c|}{ Submental ${ }^{¥}$} & $1.9 \pm 0.9$ \\
\hline \multicolumn{2}{|l|}{ Chest $^{*}$} & $5.3 \pm 3.3$ \\
\hline \multicolumn{2}{|l|}{ Total $^{¥}$} & $20.3 \pm 6.3$ \\
\hline
\end{tabular}

The total of GAGS scores were between 4 and 38 and mean GAG score of the patients was $20.3 \pm 6.3$. The highest GAGS scores were found in the chest followed by the cheek and the forehead (Table 1).

Mean DLQI and CADI scores were 6.0 \pm 4.6 and $6.1 \pm 3.0$, respectively.

There was no significant relationship between the quality of life, gender and the disease duration ( $p>0.05$ for all).However, a positive significant correlation was observed between the DLQI and the CADI scores $(r=0.639$ and $\mathrm{p}<0.001)$. 
When the DLQI and the CADI scores were compared by age, there was a significant $(r=-0.156, p=0,01$ and $r=-0.144$, $\mathrm{p}=0.017$, respectively) negative correlation between age and both scores.There was also a significant negative correlation between age of onset of the lesions and both scores $(r=-0.141, p=0.02$ and $\mathrm{r}=-0.159, \mathrm{p}=0.008$, respectively). There was a significant positive correlations between CADI scores and the GAGS scores of the forehead $(r=0.165, p=0.06)$, and the left cheek $(r=0.12, p=0.048)$. There was no significant relationship between CADI scores and the GAGS scores of the right cheek, the nose, the chin, the chest ( $>0.05$ for all) (Table 2 ).

Table 2: Relationship between the life quality scores and acne severity.

$$
\text { Global Score }
$$

Forehead Right Left Nose Submental Chest Total

\begin{tabular}{lllllllll}
\hline & $\mathrm{r}$ & 0.165 & 0.109 & 0.120 & 0.069 & 0.096 & 0.147 & 0.224 \\
CADI & $\mathrm{p}$ & 0.006 & 0.071 & 0.048 & 0.258 & 0.113 & 0.015 & 0.000 \\
& $\mathrm{r}$ & 0.093 & 0.126 & 0.054 & 0.032 & 0.015 & 0.111 & 0.150 \\
& $\mathrm{r}$ & 0.02 & \\
DLQI & $\mathrm{p}$ & 0.123 & 0.037 & 0.373 & 0.603 & 0.811 & 0.067 & 0.013 \\
& & & & & & & & \\
\hline
\end{tabular}

There was a significant positive correlation between DLQI and GAGS score of right cheek $(r=0.126, p=0.037)$. There was no significant correlation between DLQI and forehead, left cheek, nose, chin and chest GAG scores ( $p>0.05$ for all) (Table 2).

The CADI scores of the patients with forehead and upper back acne were significantly higher than the patients without forehead $(\mathrm{p}=0.012)$ or upper back acne $(\mathrm{p}=0.001)$ (Table $3)$.

The DLQI scores of the patients with upper back acne, were significantly higher than the patients without upper back acne $(\mathrm{p}=0.017)($ Table 3$)$.

Table 3: Relationship between acne localization and life quality index scores.

\begin{tabular}{|c|c|c|c|c|c|}
\hline & & $\mathrm{CADI}^{¥}$ & $\mathrm{p}$ & DLQI $^{¥}$ & $\mathrm{p}$ \\
\hline \multicolumn{6}{|l|}{ Localization } \\
\hline \multirow{2}{*}{ Forehead } & Absent & $4.4 \pm 2.9$ & \multirow{2}{*}{0.012} & $5.2 \pm 4.4$ & \multirow{2}{*}{0.40} \\
\hline & Present & $6.2 \pm 3.0$ & & $6.0 \pm 4.6$ & \\
\hline \multirow{2}{*}{ Nose } & Absent & $5.8 \pm 2.9$ & \multirow{2}{*}{0.155} & $5.8 \pm 4.4$ & \multirow{2}{*}{0.702} \\
\hline & Present & $6.4 \pm 3.1$ & & $6.1 \pm 4.7$ & \\
\hline \multirow{2}{*}{ Cheek } & Absent & $4.4 \pm 3.0$ & \multirow{2}{*}{0.148} & $4.0 \pm 4.1$ & \multirow{2}{*}{0.195} \\
\hline & Present & $6.1 \pm 3.0$ & & $6.0 \pm 4.6$ & \\
\hline \multirow{2}{*}{ Perioral } & Absent & $4.9 \pm 2.5$ & \multirow{2}{*}{0.085} & $5.1 \pm 5.1$ & \multirow{2}{*}{0.134} \\
\hline & Present & $6.2 \pm 3.1$ & & $6.0 \pm 4.5$ & \\
\hline \multirow{2}{*}{ Submental } & Absent & $5.9 \pm 3.0$ & \multirow{2}{*}{0.239} & $5.8 \pm 4.3$ & \multirow{2}{*}{0.773} \\
\hline & Present & $6.5 \pm 3.3$ & & $6.4 \pm 5.4$ & \\
\hline \multirow{2}{*}{ Submandibular } & Absent & $6.0 \pm 2.9$ & \multirow{2}{*}{0.774} & $6.0 \pm 4.4$ & \multirow{2}{*}{0.787} \\
\hline & Present & $6.1 \pm 3.1$ & & $6.0 \pm 4.7$ & \\
\hline \multirow{2}{*}{ Chest } & Absent & $5.8 \pm 3.0$ & \multirow{2}{*}{0.086} & $5.4 \pm 4.2$ & \multirow{2}{*}{0.063} \\
\hline & Present & $6.3 \pm 3.0$ & & $6.4 \pm 4.8$ & \\
\hline \multirow{2}{*}{ Upper back } & Absent & $5.2 \pm 3.0$ & \multirow{2}{*}{0.001} & $5.0 \pm 4.2$ & \multirow{2}{*}{0.017} \\
\hline & Present & $6.4 \pm 3.0$ & & $6.4 \pm 4.7$ & \\
\hline \multirow{2}{*}{ Lower back } & Absent & $6.1 \pm 3.0$ & \multirow{2}{*}{0.924} & $6.1 \pm 4.4$ & \multirow{2}{*}{0.245} \\
\hline & Present & $6.1 \pm 3.3$ & & $5.6 \pm 5.3$ & \\
\hline
\end{tabular}

$¥: m e a n \pm$ standard deviation.

\section{Discussion}

Acne vulgaris is a common skin disorder that mostly occurs in adolescence and located on the face. Therefore, it has important effects on psychosocial life of the patients [8]. Psychological involvements include depression, anxiety, social isolation and suicidal ideation or intent [9]. After understanding the psychosocial effects of acne vulgaris on patients, quality of life indexes are used to evaluate and follow up of treatment [10].

In recent years, the use of DLQI and CADI scales in the assessment of quality of life in patients with acne vulgaris have been increased. Both DLQI and CADI scales have been translated into various languages and validated [6, 11-13] and after that, quality of life studies in acne vulgaris accelerated.

The mean DLQI and CADI scores in our study were similar to previous studies [10, 14-18]. However, the studies performed on students at their school, reported lower DLQI and CADI scores $[19,20]$. This may be related to the fact that the patients included in our study were those who referred to dermatology outpatient clinic and probably experienced more discomfort than others.

There was no significant difference in the quality of life based on gender that is similar to the results of Safizadeh and Yazıc1 studies [18, 21].

While some authors found significant relationship between acne severity and quality of life; some of them did not report any significant relationship [10,16-18, 22-26]. The differences in the findings of various studies higlight the social, behavioral and cultural factors, differences in population characteristics and individual perception. In our study, both the CADI and the DLQI scores were in postive correlaiton with GAGS score as previous studies [14, 22, 27, 28]. Unlike the CADI score; the DLQI score was not corralated with GAGS score among patients who have acne lesions on forehead. Since majority of acne patients are consist of forehead localized acne lesions, CADI score might be a more appropriate scale for evaulating acne patinets' life quality rather than the DLQI score. Although the DLQI is widely used and eligible life quality scale for the dermaotlogic diseases, we believe disease-spesific scales should be developed and used for disease-based studies.

Limitation of our study was that the patients included in the study were not questioned for comorbid dermatologic diseases except acne vulgaris, and therefore the DLQI scale might be affected by these additional diseases.

As a conclusion, in patients with forehead localized acne (majority of patients in our study), unlike the DLQI, a positive correlation between the CADI and acne severity, suggested that the CADI might be more appropriate for assessing the quality of life in acne vulgaris. At the same time, the CADI scale has less questions than the DLQI and this might make it easier to perform.

\section{References}

1. Ogedegbe EE, Henshaw EB. Severity and impact of acne vulgaris on the quality of life of adolescents in Nigeria. Clin Cosmet Investig Dermatol. 2014;7:329-34

2. Hazarika N, Archana M. The Psychosocial Impact of Acne Vulgaris Indian JDermatol. 2016;61:515-20.

3. World Health Organization. Division of Mental Health and Prevention of Substance Abuse. (1997). WHOQOL : measuring quality of life. World Health Organization. Available from https://apps.who.int/iris/handle/10665/63482

4. Barnes LE, Levender MM, Fleischer AB Jr, Feldman SR. Quality of life measures for acne patients. Dermatol Clin. 2012;30:293-300.

5. Doshi A, Zaheer A, Stiller MJ. A comparison of current acne grading systemsand proposal of a novel system. Int J Dermatol. 1997;36:416-8.

6. Dréno B. Assessing quality of life in patients with acne vulgaris:implications for treatment. Am J Clin Dermatol. 2006;7:99-106.

7. Grando LR, Horn R, Cunha VT, Cestari TF. Translation, cultural adaptation and validation for Brazilian Portuguese of the Cardiff Acne Disability Indexinstrument. An Bras Dermatol. 2016;91:180-6.

8. Mulder MM, Sigurdsson V, van Zuuren EJ, Klaassen EJ, Faber JA, de Wit JB, van Vloten WA. Psychosocial impact of acne vulgaris. evaluation of the relation between a change in clinical acne severity and psychosocial state. Dermatology.2001;203:124-30. 
9. Fried RG, Wechsler A. Psychological problems in the acne patient. Dermatol Ther. 2006;19:237-40.

10. Ghaderi R, Saadatjoo A, Ghaderi F. Evaluating of life quality in patients with acne vulgaris using generic and specific questionnaires. Dermatol Res Pract. 2013;2013:108624.

11. Jankovic S, Vukicevic J, Djordjevic S, Jankovic J, Marinkovic J, Basra MK. The Cardiff Acne Disability Index (CADI): linguistic and cultural validation in Serbian. Qual Life Res. 2013;22:161-66.

12. Law MP, Chuh AA, Lee A. Validation of a Chinese version of the Cardiff Acne Disability Index. Hong Kong Med J. 2009;15:12-7.

13. Ozturkcan S, Ermertcan AT, Eser E, Sahin MT. Cross validation of the Turkish version of dermatology life quality index. Int J Dermatol. 2006;45:13007.

14. Durai PC, Nair DG. Acne vulgaris and quality of life among young adults in South India. Indian J Dermatol. 2015;60:33-40.

15. Salman A, Kurt E, Topcuoglu V, Demircay Z. Social Anxiety and Quality of Life in Vitiligo and Acne Patients with Facial Involvement: A Cross-Sectional Controlled Study. Am J Clin Dermatol. 2016;17:30511.

16. Gupta A, Sharma YK, Dash KN, Chaudhari ND, Jethani S. Quality of life in acne vulgaris: Relationship to clinical severity and demographic data. Indian J Dermatol Venereol Leprol. 2016;82:292-7.

17. Yap FB. Cardiff acne disability index in Sarawak, Malaysia. Ann Dermatol. 2012;24:158-61.

18. Safizadeh H, Shamsi-Meymandy S, Naeimi A. Quality of life in Iranian patients with acne. Dermatol Res Pract. 2012;2012:571516.

19. Hanisah A, Omar K, Shah SA. Prevalence of acne and its impact on the quality of life in school-aged adolescents in Malaysia. J Prim Health Care. 2009;1:20-5.

20. Law MPM, Chuh AAT, Lee A, Molinari N. Acne prevalence and beyond: acne disability and its predictive factors among Chinese late adolescents in Hong Kong. Clin Exp Dermatol. 2010;35:16-21.

21. Yazici K, Baz K, Yazici AE, Köktürk A, Tot S, Demirseren D, et al. Disease-specific quality of life is associated with anxiety and depression in patients with acne. J Eur Acad Dermatol Venereol.. 2004;18:435-9.

22. El-Hamd MA, Nada EEA, Moustafa MA, Mahboob-Allah RA. Prevalence of acnevulgaris and its impact of the quality of life among secondary school-agedadolescents in Sohag Province, Upper Egypt. J Cosmet Dermatol. 2017;1:370-3.

23. Ilgen E, Derya A. There is no correlation between acne severity and AQOLS/DLQI scores. J Dermatol. 2005;32:705-10.

24. Hazarika N, Rajaprabha RK. Assessment of Life Quality Index Among Patients with Acne Vulgaris in a Suburban Population. Indian J Dermatol. 2016;61:163-8.

25. Awad SM, Morsy H, Sayed AA, Mohamed NA, Ezzat GM, Noaman MM. Oxidative stress and psychiatric morbidity in patients with facial acne. J Cosmet Dermatol. 2018;17:203-8.

26. Basak PY, Ergin S. Effects of acne vulgaris on quality of life. Türkderm,2000;34:107-9.

27. El-Khateeb EA, Khafagy NH, Abd Elaziz KM, Shedid AM. Acne vulgaris: prevalence, beliefs, patients' attitudes, severity and impact on quality of life in Egypt. Public Health. 2014;128:576-8.

28. Lukaviciute L, Navickas P, Navickas A, Grigaitiene J, Ganceviciene R, Zouboulis CC. Quality of life, anxiety prevalence, depression symptomatology and suicidal ideation among acne patients in Lithuania. J Eur Acad Dermatol Venereol. 2017;31:1900-6. 